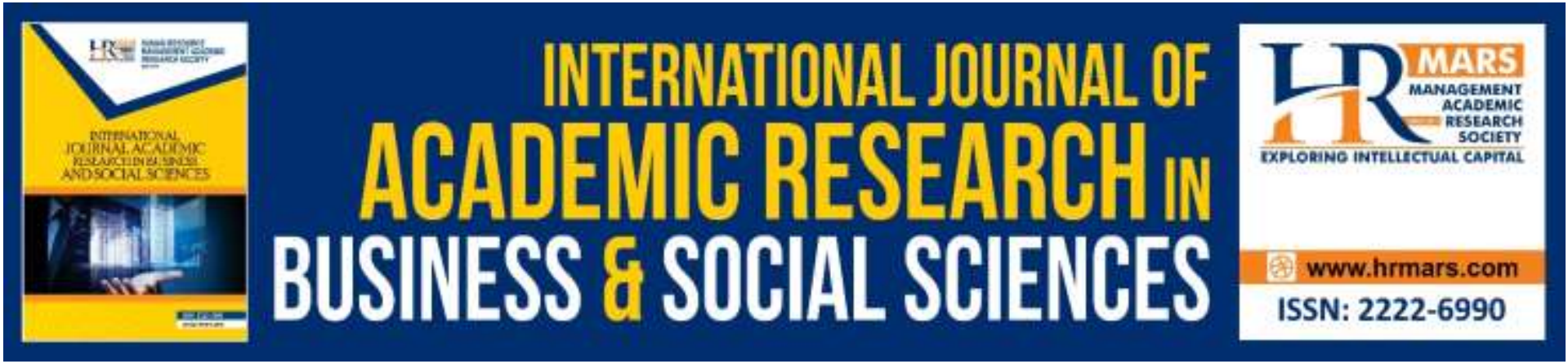

\title{
Leadership Development Process: Positive Youth Development through Coaching among Youth Leaders
}

\author{
Mohd Mursyid Arshad, Nasreen Khanum Nawab Khan \& Ismi Arif Ismail
}

To Link this Article: http://dx.doi.org/10.6007/IJARBSS/v11-i17/11390～DOI:10.6007/IJARBSS/v11-i17/11390

Received: 04 August 2021, Revised: 28 August 2021, Accepted: 23 September 2021

Published Online: 21 October 2021

In-Text Citation: (Arshad et al., 2021)

To Cite this Article: Arshad, M. M., Khan, N. K. N., \& Ismail, I. A. (2021). Leadership Development Process: Positive Youth Development through Coaching among Youth Leaders. International Journal of Academic Research in Business and Social Sciences, 11(17), 47-61.

Copyright: (C) 2021 The Author(s)

Published by Human Resource Management Academic Research Society (www.hrmars.com)

This article is published under the Creative Commons Attribution (CC BY 4.0) license. Anyone may reproduce, distribute, translate and create derivative works of this article (for both commercial and non-commercial purposes), subject to full attribution to the original publication and authors. The full terms of this license may be seen at: http://creativecommons.org/licences/by/4.0/legalcode

Special Issue Title: Empowering Community and Beyond, iRandau, 2021, Pg. 47 - 61

Full Terms \& Conditions of access and use can be found at http://hrmars.com/index.php/pages/detail/publication-ethics 


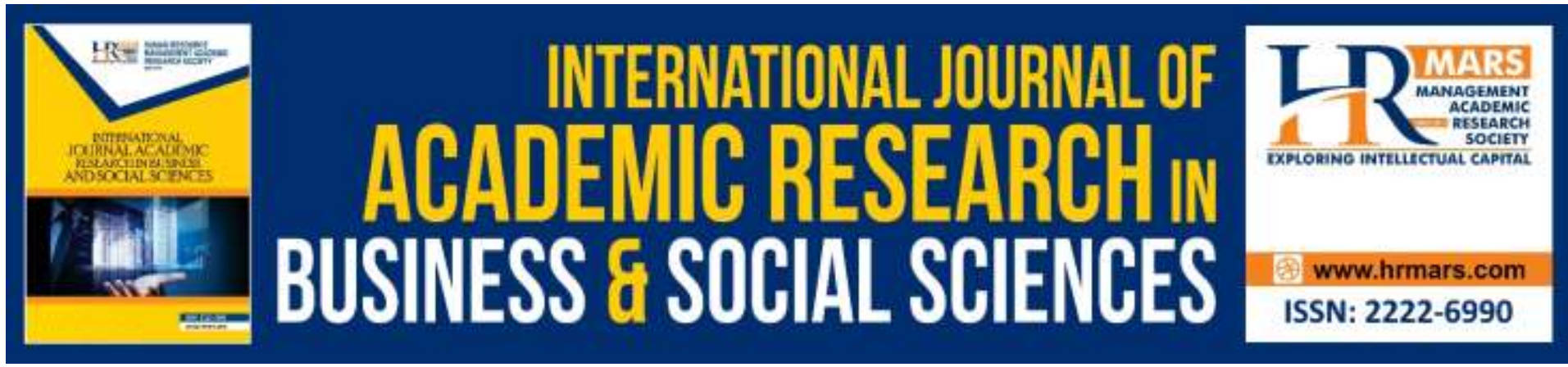

\title{
Leadership Development Process: Positive Youth Development through Coaching among Youth Leaders
}

\author{
Mohd Mursyid Arshad', Nasreen Khanum Nawab Khan² \& Ismi \\ Arif Ismail $\left.\right|^{3}$ \\ 1,3 Institute for Social Science Studies, Universiti Putra Malaysia, 43400, Serdang, Malaysia \\ ${ }^{2}$ Faculty of Educational Studies, Universiti Putra Malaysia, 43400, Serdang, Malaysia \\ Email: m_mursyid@upm.edu.my
}

\begin{abstract}
Youth leadership is an element critically needed in nation building agenda. The establishment of youth leadership will form the line of successors that will maneuver the socioeconomic and political landscape. The involvement of new youth leadership talent can be enhanced through wider exposure and professional training, including via coaching. This paper discusses the potential of coaching in youth leadership development program on positive youth development. Besides the development of internal asset such as leadership skill enhancement, to what extent does coaching provide the opportunity for youth to harness one's ecological asset through the access possessed by coach? The link between coaching and youth leadership development is viewed through its contribution to positive youth development.
\end{abstract}

Keywords: Positive Youth Development, Coaching, Leadership, Youth Leaders

\section{Introduction}

Youth development is described as an ongoing process to meet the physical needs and social demands in building youth competency (Delgado, 2002), which in turn, promotes positive youth development (PYD) (Lerner et al., 2005). According to Li and Wang (2009), youth involvement in leadership activities is one of the approaches in the PYD concept as it involves youth development process. The focus on PYD process serves as the basis for developing positive youth elements in self potential (Sherrod, 2007; Ward, 2008), which principally require empirical understanding to reveal the potential of youth leadership talent on PYD through coaching.

Youth leaders today consist of youths referred to as Generation $Y$ or Millennials (Hershatter \& Epstein, 2010; Cennamo \& Gardner, 2011). It is evident that youth development has a strong connection with youth development efforts, which can be viewed as an ongoing process towards achieving physical necessities and social needs and building competency and network through youth involvement (Delgado, 2002). Hence, the Malaysian governments' initiative is continued in a long-term plan through the Government 
Transformation Programme (GTP), under the Economic Transformation Program (ETP), with an emphasis on human capital development, specifically on mobilization of resources among youths (Ramasamy \& Rowley, 2013). Due to the rapid development of technology in this globalized era, youths as leaders of tomorrow are expected to be outstandingly talented, competent, knowledgeable, and possess high expertise as leaders (Khairuddin et al., 2009). Therefore, to empower youths, efforts on youth development have been emphasized since the Ninth Malaysia Plan 2006-2010 (Ninth Malaysia Plan, 2006), and still continue today to increase youths' potential and productivity.

In other developing countries, youth development programmes at the national level have been implemented to generate successors of great leaders (Solansky, 2010; Christens \& Dolan, 2011). Among the programs are; 'White House Fellow' in the United States of America, 'Headteacher Trainee' and 'Future Leaders' programmes conducted by the National College for School Leadership in England (Earley, 2009). According to Garcia (2009), these youth leadership programmes serve as a platform in preparing young leaders who are highly motivated and directly involved in the administration process at the national level and also involved in community development.

However, Hastings, Human, and Bell (2011) discovered that as leaders, youths often fail to see themselves as decision-makers because the adult leaders do not pass on the skills, experience, needs and motivation on how to be leaders systematically to them. The continuity of guiding youth leadership, if not well planned, may cause the young leaders not being able to control and arrange for the existing community development process, which will then, lead to having youths who are not strongly connected to the community (Christens \& Dolan, 2011). Therefore, the question arises how the PYD can be associated with the process of coaching in youth leadership development to expedite the process of forming a new leadership successor in the future.

\section{Literature Review}

\section{Generation Gap in Leadership}

From the leadership development aspect, Northouse's (2007) model of leadership traits explains that intellectual ability, high confidence level, ensuring the success of a task, integrity and social skills are the elements required in developing leaders. To determine the type of leadership desired, the Six Domains of Leadership Model mentions that the development of leadership skills is up until the monitoring level (Sitkin \& Lind, 2006). Hence, to explore the process of leadership development skills, the coaching technique (ReaganPorras, 2013) provides the perspective of acquiring knowledge and social skills, which also incorporates the process of legitimate peripheral participation (Lave \& Wenger, 1991; Wenger, 1998; Wenger et al., 2002).

Leadership coaching takes place in most organizations to fulfill the purpose of preparing future leaders and successors of the organization (Smolter, 2011; Murphy, 2012). Usually, coach come from a different generation than the coachee (Bickel \& Brown, 2005; Chen \& Krauskopf, 2013) and this does not necessarily depend on age (Harvey et al., 2009). Adult coach may not experience any problem to socialize and communicate with youths as their coachee, but they may have different interpretations during the two-way communication (Reagan- Porras, 2013). In the context of today's youth leadership development, coachee born between 1980 to 2000 are known as Generation Y or Millennial (Hershatter \& Epstein, 2010), compared to the more senior coach from Generation X or Baby Boomers (Dannar, 2013). 
The generation differences in coaching bring a great implication that influences the role of leadership in the medical field and healthcare (Hershatter \& Epstein, 2010; Cennamo \& Gardner, 2011). Each of them had different environmental experiences that shaped varied expectations and actions (Chen \& Krauskopf, 2013), and leadership patterns (Smolter, 2011). The generation gap in youth leadership coaching allows for a deeper exploration on how the process happens effectively which includes the compatibility between coach and coachee from different generations. This is because, according to Kram and Ragins' (2007) coaching theory, coaching process is not static, in which it portrays different functions, experiences and forms of interaction that may be expanded in youth development. Youth potential in leadership can be amplified through developmental programmes (MacNeil, 2006; Hastings, Human \& Bell, 2011; Reagan-Porras, 2013). The emphasis on reciprocal learning through coaching requires coachee to develop positive values through the roles they play in mirroring what have been done by their coach (Schwartz et al., 2013).

\section{Positive Youth Development (PYD) in the leadership development process}

From the youth leadership aspect, knowledge formation process, behaviour and positive attitude of the participants cultivated from the leadership development programmes may be an indicator of the production of positive youth development (Lerner, 2005; Silbereisen \& Lerner, 2007; Lerner et al., 2011). Therefore, the aspect of planning youth development programmes is encouraged to take into account the current needs of youths (Cullen \& Bradford, 2012). A proper planning of developmental programmes will explain in detail the learning outcomes based on the objectives reached (Caffarella, 2002). This is the main element in planning leadership developmental programmes that focuses on youths. Effective coaching enables the development of youth potential by providing them with the opportunity to develop life and leadership skills, which in turn, will enhance positive youth development (Lerner et al., 2013). With that, youths may give their contributions through youth development programmes as a medium to create an ongoing relationship with their coach who have provided the opportunity for skills development of the youths (Karcher \& Hansen, 2013).

Positive youth development (PYD) perspective basically combines two main ideas. The first perspective is that youths possess the strength as displayed through the development of their ability in cognitive, emotion, social and behavioural changes (Lerner, Brittian \& Fay, 2007; Phelps et al., 2009; Gestsdottir et al., 2011). Furthermore, the second perspective is the hypothesis assuming that the PYD element will increase when the youth strength is compatible with the strength to react to their surrounding (Benson, Skala, Hamilton, \& Sesma, 2006), for a healthy development in their ecology. The individual development process in the PYD context involves adaptation of developmental regulations between youth strength and asset development within a particular ecology (Phelps et al., 2009).

The PYD perspective initially stems from the positive psychological concept,which appears as a result to comparisons made by psychologists and biologists studying plasticity in the development process emerging from the combination process. To relate the concept of knowledge engineered in this study, the system of theory development such as individual contextualism development has emphasized on plasticity that exist in human development. Specifically, the perspective towards PYD may be narrowed down to the following: 
"The Positive Youth Development (PYD) perspective is an orientation to young people that has arisen because of interest among developmental scientists in using development systems, or dynamic, models of human behavior and development for understanding the plasticity of human development and the importance of relations between individuals and their realworld ecological settings as bases of variation in the course of human development" (Sibereisen \& Lerner, 2007, p.3)

The term 'plasticity' is a potential for a more systematic change in human development, which instills positive elements (Lerner et al., 2005; Lerner, Brittian \& Fay, 2007). Therefore, the process requires internal and external support. According to Theokas et al. (2005), the combination of internal and external situations for the development of PYD elements above mentioned are known as the ecological and individual assets (Lerner et al., 2012). The internal asset is an element that guides youths to make choices related to their strengths, that is their hopeful future expectation, internal self-regulation and positive school engagement. Meanwhile, the external assets are ecological assets mostly related to positive experiences obtained from others, and the institutions they are involved with (Lerner et al., 2012). This may lead to individual joined benefit as the context of relationship with PYD consist of five elements ' $5 C$ ' (Lerner et al., 2005), illustrated in Figure 1 as follows:

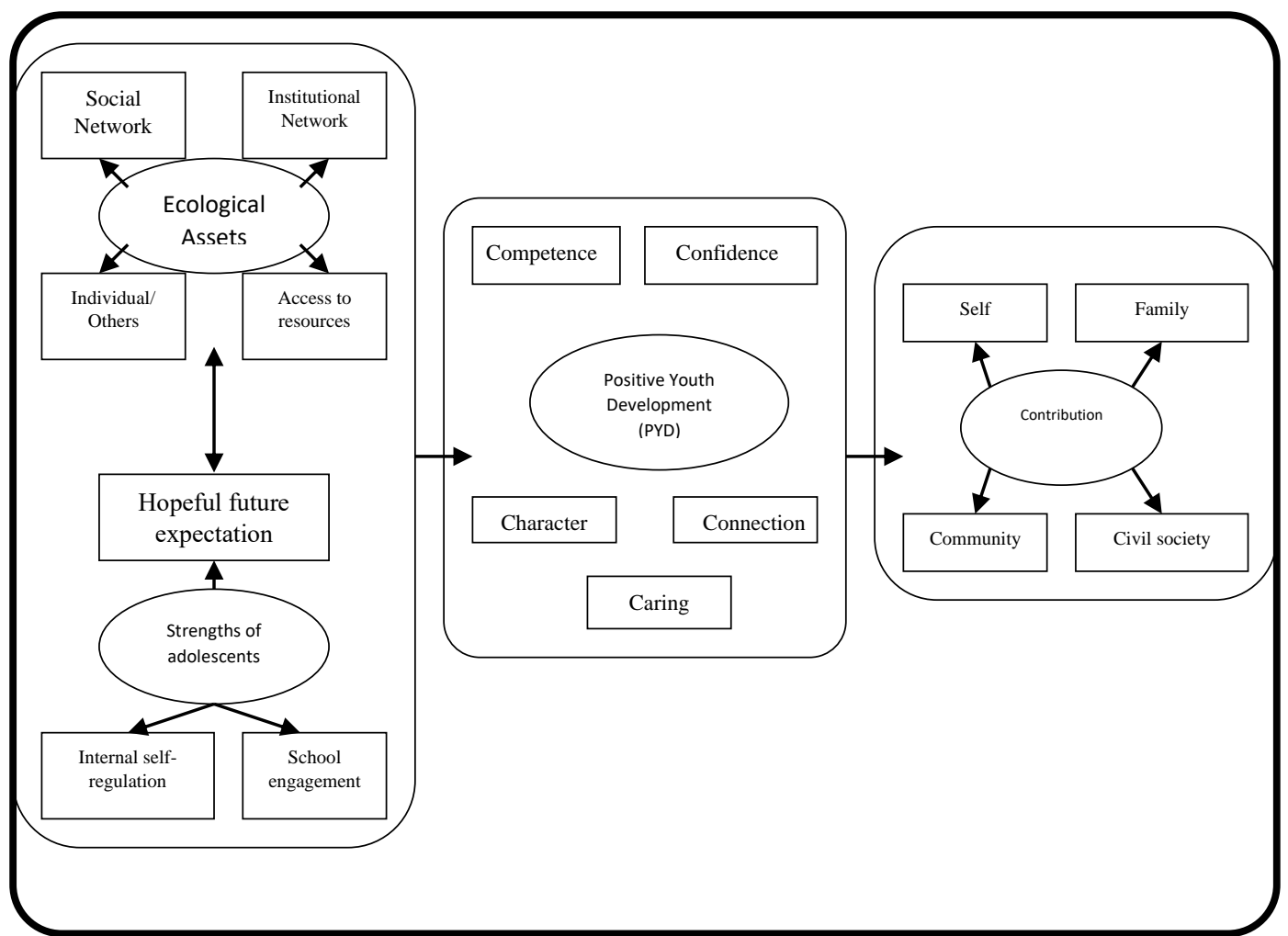

Figure 1: The relational, developmental systems model of Positive Individual involved in PYD (Lerner et al., 2005, p.7)

Theoretically, the ecological assets are associated with the developmental process of positive youths, consisting of the ' $5 \mathrm{Cs}^{\prime}$ ' that encourage positive behaviour among youths (Lerner, Brittian \& Fay, 2007). Based on the works of Lerner et al (2005), there are several specific steps that could be taken by the coach to instill all the five ' $C$ ' elements within their coachee to ensure a more effective process in youth development. The theory of 
developmental systems explains that the changes in coachee development is assisted by the coach by placing positive development as one of the life expectancy processes whereby the individual and the context (related environment) are dynamically combined throughout the mutually beneficial interaction in coaching (Lerner, 2004: DuBois et al., 2011). When the individual and potential contexts for plasticity in human development to occur are acknowledged, this will directly lead to building positive individual potential which includes the aspects of healthcare (Larson, 2006). Therefore, the developmental system theory is also embedded in the youth development process, which is linked to positive youth development (Theokas et al., 2005).

Through coaching, youths are given the opportunity to develop skills, shape youth leadership and continuity hence maintain the relationship between the youths (coachee) and adults (coach). The advantage obtained by the youths through leadership coaching is associated with the effective youth development criteria. Besides that, it provides the opportunity for the youths to gain access through the ecological asset via the community they are involved in, and this will directly develop each of the ' $5 \mathrm{Cs}$ ' element in developing positive youths, which in the end shall be the contribution made by the youths (Lerner et al., 2011; Lerner et al., 2012).

\section{Coaching in Leadership Development}

The overwhelmingly demanding world today demand for high quality leaders (Mihiotis \& Argirou, 2016; Anderson \& Anderson, 2016). Leaders should continually equip themselves with necessary skills to anticipate the changing environment which drive pressure for a more effective leadership development, especially in private organizations. In relation to this, coaching has emerged in the human resource development practice as a powerful development tool in improving leadership skills of executive leaders (Cox, 2015).

To date, more and more organizations are investing in putting together coaching programs in place. The goal of coaching is to improve a leader's effectiveness to ensure sustainability and organizational success (Cox, 2015). One aspect that coachee discovered from their participation in a mid to long-term coaching program is that it improves their flexibility in terms of mindset, behaviors, and their decision-making process (Densten \& Grey, 2001). It helps the coachee to operate in a more open paradigm, moving away from rigidity and fixed solutions which enhance the capacity and potential of coachee (Speltz, 2013).

Powerful questioning and critical reflection play a vital role in challenging conventional thinking to consider other viewpoints and allowing coachee to assess their situation deeper. Brookfield (2003) suggested that critical reflection is a deeper, more intense inquiry to assess current reality and making sense of the situation from various viewpoints along with limiting beliefs and biases. Effectiveness of reflective practice is determined by how effective an individual can learn from their personal experience. Critical reflection facilitates formation of new knowledge and new behaviours by making meaning through experience (Rigg \& Trehan, 2008). Ulrich (2008) highlighted that powerful questioning is helpful in promoting coachee to be involved in a reflection process. Powerful questioning challenges the status quo of coachee's belief and presumptions (Hemphill, 2014). This process helps to improve coachee's leadership development by encouraging coachee to be flexible in their approach allowing themselves to be detached from their personal assumption and belief, while examining different views and perspective (Densten \& Grey, 2001).

Arnold (2016) highlighted that a leader must be able to be flexible enough to change accordingly to address to the situational needs. Ronen (1989) suggested that flexible leader 
has the ability to manage complexity and uncertainty, display adaptability, tolerate ambiguity, anticipate changes, display openness, empathy, and a willingness to acquire new behaviors and attitudes. Three main skills of listening, questioning and contemplation have been used for productive and advanced coaching in order to create high impact, successful conversation and training (Starr, 2016). Strong questioning by coaches promotes the process of instilling inspiration and reflection in coaches. (Arnold, 2016). Coaching provides a healthy forum for thinking and room for more development and progress (Ingleton, 2013). The act of prompting questions to coachee is aimed at enabling coachee to evaluate their situation and to find solutions to their own problems (Arnold, 2016). The ability to use open ended questions is the key to develop a deeper understanding of a coachee's personal perception (Cox, 2015)

\section{Youth leadership development and its relationship with coaching}

Coaching has gained acceptance (Bozer, Sarros \& Santora, 2014) a major development method thanks to their complexities that combine many disciplines capable of addressing diverse needs in the evolving and competitive climate. Coaching may be applied for various purposes, including development, performance, professional development, and training programs (Griffiths \& Campbell, 2016; Ingleton, 2013). While different types of coaching are implemented on the market, numerous commonalities can be found in different applications such as the common goal-directed and solution-focused framework (Griffiths \& Campbell 2016).

The coaching process is encouraged by assisting and systematically developing executives in any defined area of growth that may be relevant to work or personal development. Coaching processes are able to allow people to step back and objectively evaluate themselves from third-party perspectives. It allows the top management to understand themselves coherently as it improves and encourages self-confidence among people who embrace prodigious potential for self-improvement. (Anderson \& Anderson, 2016; Bozer, Sarros \& Santora, 2014).

Coachee, who can easily adapt into any environment including the coaching environment by the coach during the coaching process, will be viewed as individuals with potentials to elevate their self-development and contribute towards positive development of oneself, family, the community, and civil society (Theokas et al., 2005). The final outcome of youth leadership coaching would be positive youth contribution, which is an intervention in producing potential youths through their contribution towards self, family, community and civil society (Lerner et al., 2005). Figure 3 below illustrates the criteria required for youth development that may be embedded in the coaching approach during the implementation of a developmental program.

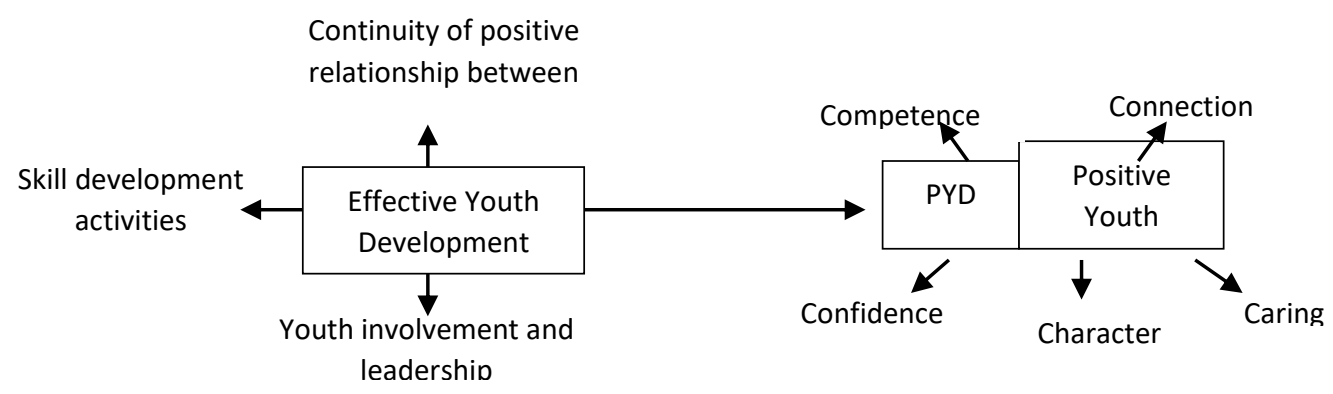

Figure 3: Effective Youth Development Model (Lerner et al., 2007) 
In cultivating and encouraging both elements, namely, the development of PYD characteristics and positive youth contribution in youth development process, coach need to play their roles in determining their interaction with the coachee in coaching so as to mirror the three important aspects (skills development, youth leadership development, and continuity relationship between adults and youths) (Lerner et al., 2007). Learning from coach includes the behaviours displayed by coach, which contributes to the formation of charismatic values of the coachee and the coachee' commitment towards the transformations done earlier (Blass \& Ferris, 2007; Ragins \& Kram, 2007, Eby et al., 2013; Sanfey et al., 2013).

Effective coaching enables the development of youth potential by providing opportunities for youths to build up living skills and leadership skills that will assist in the development of positive youths (Lerner et al., 2013). With that, youths may contribute something through youth developmental programs as a medium to create an ongoing relationship with the coach who have provided the opportunity for the youths' skills development (Lerner, 2004; Rhodes \& DuBois, 2008).

\section{PYD Dissemination in Youth Leadership Development through Coaching}

The dynamic coaching theory explains that coaching learning principals involve the relationship between coach and coachee, whereby the coachee' learning is based on their observation on demonstrations and coach' learning support (Lerner et al., 2005). Learning transfer can be more meaningful in the social and physical context in the situated contexts (Lave, 1988; Lave \& Wenger, 1991), which is interdependent on the form of activities, concept and culture (Brown et al., 1989; DuBois et al., 2011; Pryce \& Keller, 2013). Therefore, learning methods in leadership development process is also dependent on organizational culture that may influence leadership style (Holt, Bjorklund \& Green, 2009; Caldwell \& Dixon, 2010).

Based on actual situations in leadership, Hofstede and Hofstede (2005), Hofstede (2007) and Jogulu (2010) discovered that Malaysia is a country with a high 'power distance' culture in organizational leadership where followers find it easier to receive orders and tutoring from leaders since they pay a high level of respect towards the more powerful individuals. On contrary, in low power distance culture, roles and responsibilities of the followers may change according to an individual's effort and achievements (Hofstede \& Hofstede, 2005), whereby each individual has the freedom and choice in the relationship between superior and follower (Khatri, 2009; Jogulu, 2010). Hence, youth developmental programs, especially leadership development program require continuous effort from various parties in producing quality human capital to prepare for the future. According to $\mathrm{Li}$ and Wang (2009), youth involvement in leadership activities is one of the approaches in the PYD concept. The focus on PYD is the basis to developing positive youth elements (Sherrod, 2007; Ward, 2008), which principally requires empirical understanding to uncover youth coaching potentials in PYD development through leadership.

The coaching method is seen to have the potential in preparing a platform and opens doors for youth leadership development through access to networking with other individuals, social networks, institutions and access to resources which are the elements in the ecological asset as discussed by Lerner et al (2005). In coaching, a coachee has the potential to acquire knowledge and leadership skills from the coach, both formally and informally. 
Therefore, the first step to apply PYD elements in coaching is by employing the approach as suggested by Delgado (2002), that is, to identify the needs of coachee and then build the competency in preparing youths to become successful adults by not just looking at them as individuals without potential. The next step is for coach with potentials in leadership skills to delve into on the coachee' ability as a resource that can be developed and build their strength and ability in leadership. This approach is in line with Lerner et al (2013) suggested that PYD is an element to develop youth potential.

The third step is to build leadership developmental process, where both parties, namely the coach and coachee collaboratively decide on the potentials that should be achieved and support each other's effort to achieve the desired leadership potential (Lerner et al., 2005). This approach directly explains how the community, during the coaching process support youth leadership development in a competent and healthy way, and at the same time develop their real potentials (Lerner, 2009).

The next step is for coach to responsibly play their roles to provide the coachee some space for themselves to easily adapt into different environments and situations. The influence that coach have on their coachee during the coaching process allows youths to be seen as individuals with the potential to develop themselves and the civil society (Theokas, et al., 2005). Leadership coaching gives youth leaders the opportunity and freedom to make themselves worthy through the contributions given in the application of PYD elements (Benson et al., 2011). To encourage both elements, coach should ensure that the form of interaction with their coachee in coaching mirrors three aspects which are skills development, leadership development and relationship continuity, even after they have ended their formal coaching.

To empower coaching potentials, coach is encouraged to play their role of guiding youth leaders by connecting them to networks with other individuals, and also social networks by exposing them to other established institutions from the community practices in organizations. Wider exposures, for example, in societal leaderships, and regional organizational bodies at the international level may prepare youth leaders as resource connector agents. Figure 4 provides an illustration of coaching potential in opening doors and expediting the coachee's learning process to strengthen the internal assets and gain access to ecological assets which in the end will contribute to the formation of an individual's '5Cs'.

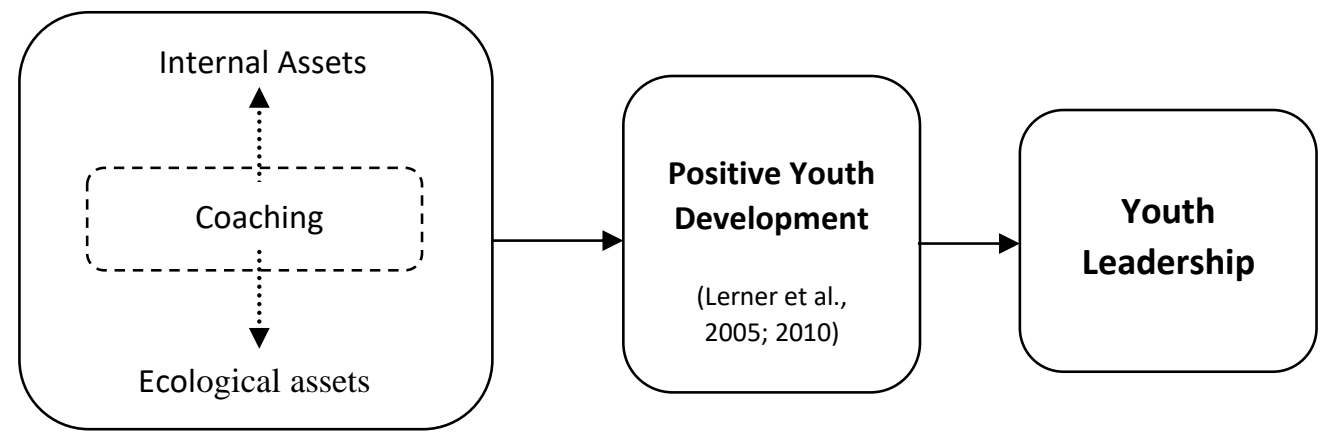

Figure 4: Coaching potentials through PYD

Coaching potential requires in-depth studies to explore the coaching experience gained by the coachee and how the coachee learn from their coach. To conclude, the empirical support obtained by youths through coaching method may build positive youth development concept through the ' $5 C^{\prime}$ '. Therefore, according to Lerner et al. (2005), youth 
developmental programs are known as the medium that play continuous role as enablers to the PYD process. Youths should be seen as a resource that can be developed (Delgado, 2002; Lerner et al., 2012). Every youth individual has the potential to succeed, experience healthy self-development and possess the ability for positive self-development (Balsano et al., 2009). Hence, to ensure that the coaching experienced by the youths is effective to them, quality coaching relationship between coach and coachee plays an important role, alongside the development of internal and ecological assets which will assist positive development in the youths' lives. Youth development, in reality, is not difficult to be applied in multidisciplinary, interdisciplinary and interactive endeavors (Benson et al., 2011).

\section{Conclusion}

The previous discussions suggest that the influence of coaching is one of the factors that assist in the formation of new leadership potentials among youths. The identification of this element will support researchers to open doors to explore the Malaysian youths' involvement in leadership development via coaching, which may contribute to positive youth development. Efforts made on youth development through leadership process could elevate positive values within youths. Generally, positive values discussed from the PYD perspective have also reviewed traditional youth services, which also include services for the community and organization. Therefore, it can be seen that the PYD values have strong relationship with leadership values shaped through coaching.

The effectiveness of youth coaching programs is also directly dependent on the planning of leadership development programs. The ability of coaching technique in developing youth leadership can be seen more clearly if the process of knowledge development, attitude and practice are cultivated to contribute to a deeper understanding in a case study. However, the coaching process is not just a simple or easy knowledge transmission to measure in the form of skills, since it also focuses on how far true leadership quality incorporates the PYD elements in youth development processes.

According to Delgado (2002), youth developmental process should identify the needs and competency required by youths in preparing youths as successful adults, and not only seeing youths as individuals without potentials. The PYD approach views youths as resources and develops their strength and ability in the community. Based on this association, the relationships between individual and ecological assets that have been developed have increased youths' potential (Lerner et al., 2012). This may be extended to the context of youth leadership development.

The current necessities and technology advancement in this globalized era deem for new leadership successors in the future, demanding for youths with striking leadership talents, knowledgeable, highly expert, and competent as leaders (Dannar, 2013). Therefore, the utmost priority is to ensure a structured and sustainable youth leadership development to be empowered, so that the process of producing new leadership talents among youths can be implemented according to plan, in the most effective way. Dynamic management and youth resource development may continue the leadership legacy (Murphy, 2012) to ensure that the country's future development agenda is led by high-caliber leaders.

\section{References}

Anderson, D. L., \& Anderson, M. C. (2016). Coaching That Counts. Taylor \& Francis Group. Arnold, J. (2016). Coaching Skills for Leaders in the Workplace. London. UK:Robinson. 
Balcazar, F. E., \& Keys, C. B. (2013). Goals in coaching relationship. In D. L. DuBois, \& M. J. Karcher (Eds.), The handbook of youth coaching (2nd ed.). (pp. 83-98). Thousand Oaks: Sage Publications Inc.

Balsano, A. B., Phelps, E., Theokas, C., Lerner, J. V., \& Lerner, R. M. (2009). Patterns of Early Adolescents' Participation in Youth Development Programs Having Positive Youth Development Goals. Journal of Research on Adolescence, 19(2), 249-259. doi:10.1111/j.1532-7795.2009.00595.x

Benson, P. L., Scales, P. C., \& Syvertsen, A. K. (2011). The contribution of the developmental assets framework to positive youth development theory and practice. In R. M. Lerner, J. V. Lerner, \& J. B. Benson (Eds.). Advances in child development and behavior. (pp. 125-228). Elsevier Publishing.

Bozer, G., Sarros, J. C., \& Santora, J. C. (2014). Executive Coaching: Guidelines that work. Development and Learning in Organizations: An International Journal, 28(4), 9-12.

Brookfield, S. D. (2003). A critical theory perspective on accelerated learning. San Francisco: Jossey-Bass.

Blass, F. R., \& Ferris, G. R. (2007). Leader reputation: The role of coaching, political skill, contextual learning, and adaptation. Human Resource Management, 46(1), 5-19.

Caffarella, R. S. (2002). Planning programs for adult learners. San Francisco: John Wiley \& Sons Inc.

Caldwell, C., \& Dixon, R. D. (2010). Love, forgiveness, and trust: Critical values of the modern leader. Journal of Business Ethics, 93, 91-101. http://doi.org/10.1007/s10551-0090184-z

Cennamo, L., \& Gardner, D. (2011). Generational differences in work values, outcomes and person-organisation values fit. IEEE Engineering Management Review, 39, 24-36. http://doi.org/10.1109/EMR.2011.5876170

Chao, G. T. (2007). The roots and meaning of coaching. In B. R. Ragins, \& K. E. Kram (Eds.), The handbook of coaching at work: Theory, research and practice (pp. 179-196). Thousand Oaks: Sage Publications Inc.

Chaudhuri, S., \& Ghosh, R. (2012). Reverse Coaching: A Social Exchange Tool for Keeping the Boomers Engaged and Millennials Committed. Human Resource Development Review, 11, 55-76. http://doi.org/10.1177/1534484311417562

Chen, B., \& Krauskopf, J. (2013). Integrated or disconnected? Examining formal and informal networks in a merged nonprofit organization. Nonprofit Management \& Leadership, 23(3): 325-345.

Christens, B. D., \& Dolan, T. (2011). Interweaving Youth Development, Community Development, and Social Change Through Youth Organizing. Youth \& Society, 43, 528548. http://doi.org/10.1177/0044118X10383647

Cox, E. (2015). Coaching and adult learning: Theory and practice. New Directions for Adult and Continuing Education,148:27-37.

Cullen, F., \& Bradford., S. (2012). Research and work with young people: Politics, participation and policy. In Bradford, S., \& Cullen, F. (Eds.) 2012, Research and Research Method for Youth Practitioners (pp.90-112). Oxon: Routledge.

Dannar, P. R. (2013). Millennials: What they offer our organizations and how leaders can make sure they deliver. The Journal of Values-Based Leadership, 6(1): 1-11.

Delgado, M. (2002). New frontiers for youth development in the twenty-first century revitalizing youth development. New York: Columbia University Press. 
Densten, I. L., \& Gray, J. H., (2001). Leadership Development and Reflection: What is the connection? International Journal of Educational Management, 119-124.

DuBois, D. L., Portillo, N., Rhodes, J. E., Silverthorn, N., \& Valentine, J. C. (2011). How Effective Are Coaching Programs for Youth? A Systematic Assessment of the Evidence. Psychological Science in the Public Interest, 12(2), 57-91. doi:10.1177/1529100611414806

Earley, P. (2009). Work, learning and professional practice: The role of leadership apprenticeships. (October 2013), 37-41. doi:10.1080/13632430902793718

Eby, L. T., Allen, T. D., Hoffman, B. J., Baranik, L. E., Sauer, J. B., Baldwin, S., Morrison, M. A., Kinkade, K. M., Maher, C. P., Curtis, S., \& Evans, S. C. (2013). An interdisciplinary metaanalysis of the potential antecedents, correlates, and consequences of coachee perceptions of coaching. Psychological Bulletin,139(2): 441-476. doi: $10.1037 / \mathrm{a} 0029279$

Eller, L. S., Lev, E. L., \& Feurer, A. (2013). Key components of an effective coaching relationship: A qualitative study. Nurse Education Today, 13(1), 1-6.

Erickson, L. D., McDonald, S., \& Elder, G. H. (2009). Informal Mentors and Education: Complementary or Compensatory Resources? Sociology of Education, 82, 344-367. http://doi.org/10.1177/003804070908200403

Flores, E. M. (2011). Becoming a Researcher: A Qualitative Study of the Apprenticeship Model in Doctoral Education. PhD Thesis, University of Washington.

Garcia, C. P. (2009). Leadership lessons of the white house fellows. New York: McGraw Hill.

Gestsdottir, S., Urban, J. B., Edmond, P., Lerner, J. V., \& Lerner, R. M. (2011). Intentional SelfRegulation, Ecological Assets, and Thriving in Adolescence: A Developmental Systems Model, (133), 61-76. doi:10.1002/cd

Greeson, J. K. P. (2013). Foster Youth and the Transition to Adulthood: The Theoretical and Conceptual Basis for Natural Coaching. Emerging Adulthood, 1(1), 40-51. doi:10.1177/2167696812467780

Griffiths, K., \& Campbell, M. (2009). Discovering, applyig and integrating: the process of learning in coaching. International Journal of Evidence Based Coaching and Mentoring, 16-30.

Hastings, L. J., Human, N., \& Bell, L. C. (2011). Developing a Paradigm Model of Youth Leadership Development and Community Engagement : A Grounded Theory, 52(1), 1929. http://doi.org/10.5032/jae.2011.01019

Hemphill, D. C. (2014). Coaching from the coaches' perspective: a process-oriented focus. International Journal of Mentoring and Coaching in Education, 72-85.

Hershatter, A., \& Epstein, M. (2010). Millennials and the world of work: An organization and management perspective. Journal of Business and Psychology, 25, 211-223. http://doi.org/10.1007/s10869-010-9160-y

Hofstede, G. (2007). A European in Asia. Asian Journal of Social Psychology, 10(1), 16-21.

Hofstede, G., \& Hofstede, G. J. (2005). Cultures and organizations: Software of the mind (2nd ed.). New York: McGraw-Hill.

Holt, S., Bjorklund, R., \& Green, V. (2009). Leadership and culture: Examining the relationship between cultural background and leadership perceptions. The Journal of Global Business Issues, 3(2): 149-164.

Ingleton, C. (2013). The miracle of coaching. Industrial and Commercial Training, 289- 292. Jogulu, U. D. (2010). Culturally-linked leadership styles. Leadership \& Organization Development Journal, 31(8), $705-719$. 
Karcher, M. J., \& Hansen, K. (2013). Coaching and positive youth development. In D. L. DuBois, \& M. J. Karcher (Eds.), The handbook of youth coaching (2nd ed.). (pp. 63-82). Thousand Oaks: Sage Publications Inc.

Khatri, N. (2009). Consequences of Power Distance Orientation in Organisations. The Journal of Business Perspective, 13(1), 1-9. doi: 10.1177/097226290901300101

Kiltz, G., Danzig, A., \& Szecsy, E. (2004). Learner-centered leadership: a coaching model for the professional development of school administrators. Coaching \& Tutoring: Partnership in Learning, 12(2), 135-153. doi:10.1080/1361126042000239901

Larson, R. (2006). Positive Youth Development, Willful Adolescents and Coaching, 34(6), 677689. doi:10.1002/jcop

Lave, J., \& Wenger, E. (1991). Situated learning: Legitimate peripheral participation. Cambridge: Cambridge University Press.

Leh, A. (2005). Lessons learned from service learning and reverse coaching in faculty development: A case study in technology training. Journal of Technology and Teacher Education, 13(1): 25-42.

Lerner, R. M. (2004). Diversity in individual context relations as the basis for positive development across the life span: A developmental systems perspective for theory, research, and application. Research in Human Development, 1(4): 327-346.

Lerner, R. M. (2005). Positive Youth Development, Participation in Community Youth Development Programs, and Community Contributions of Fifth-Grade Adolescents: Findings From the First Wave Of the 4-H Study of Positive Youth Development. The Journal of Early Adolescence, 25(1), 17-71. doi:10.1177/0272431604272461

Lerner, R. M., Lerner, J. V., Almerigi, J., Theokas, C., Phelps, E., Gestsdottir, S., Naudeau, S., Jelicic, H., Alberts, A. E., Ma, L., Smith, L. M., Bobek, D. L., Richman-Raphael, D., Simpson, I., Christiansen, E. D., \& Von Eye, A. (2005). Positive youth development, participation in community youth development programs, and community contributions of fifth grade adolescents: Findings from the first wave of the 4-H study of positive youth development. Journal of Early Adolescence. 25(1): 17-71.

Lerner, R. M., Brittian, A., \& Fay, K. (2007). Coaching: A Key Resource for Promoting Positive Youth Development. Research in Action, 1(1), 3-15.

Lerner, R. M. (2009). The positive youth development perspective: Theoretical and empirical bases of a strength-based approach to adolescent development. In C. R. Snyder and S. J. Lopez (Eds.), Oxford Handbook of Positive Psychology (2nd ed., pp. 149-163). Oxford, England: Oxford University Press.

Lerner, R. M., Lerner, J. V., Lewin-Bizan, S., Bowers, E. P., Boyd, M., Mueller, M., Schmid, K., Napolitano, C. (2011). Positive youth development: Processes, programs, and problematics. Journal of Youth Development, 6(3), 40-64.

Lerner, R. M., Bowers, E. P., Geldholf, G. J., Gestsdottir, S., \& Desouza, L. (2012). Promoting positive youth development in the face of contextual changes and challenges: The roles of individual strengths and ecological assets. New Directions for Youth Development,135(1), 119-28. doi: 10.1002/yd.20034

Lerner, R. M., Napolitano, C. M., Boyd, M. J., Mueller, M. K., \& Callina, K. S. (2013). Coaching and positive youth development. In D. L. DuBois, \& M. J. Karcher (Eds.), The handbook of youth coaching (2nd ed.). (pp. 17-27). Thousand Oaks: Sage Publications Inc.

Li, G., \& Wang, B. (2009). Adolescent Leadership Development: A Review. International Conference on Teaching and Computational Science (WTCS 2009) Proceedings (pp. 753-758). Shenzhen: Advances in Intelligent and Soft Computing. 
MacNeil, C. A. (2006). Bridging generations: Applying "adult" leadership theories to youth leadership development. New Directions for Youth Development, 109(1), 27-43.

Malaysian Youth Index. (2011). Institut Penyelidikan Pembangunan Belia Malaysia. Putrajaya: IPPBM KBS.

Meister, J. D., \& Willyerd, K. (2010). The 2020 workplace: How innovative companies attract, develop, and keep tomorrow's employees today. New York, NY: Harper Collins.

Mihiotis, A., \& Argirou, N. (2016). Coaching: from challenge to opportunity. Journal of Management Development, 35(4), 448-463.

Murphy, W. M. (2012). Reverse coaching at work: Fostering cross generational learning and developing millenial leaders. Human Resource Management, 51(4), 549-574. doi:10.1002/hrm.21489

Ninth Malaysia Plan. (2006). Retrieved from http://www.epu.gov.my/eputheme/rm9/html/english.htm

Northouse, P. G. (2007). Leadership: Theory and practice. Thousand Oaks: Sage Publications.

Parise, M. R., \& Forret, M. L. (2008). Formal coaching programs: The relationship of program design and support to mentors' perceptions of benefits and costs. Journal of Vocational Behavior, 72(2), 225-240. http://doi.org/10.1016/j.jvb.2007.10.011

Phelps, E., Zimmerman, S., Warren, A. E. A., Jeličič, H., von Eye, A., \& Lerner, R. M. (2009). The structure and developmental course of Positive Youth Development (PYD) in early adolescence: Implications for theory and practice. Journal of Applied Developmental Psychology, 30(5), 571-584.

Pryce, J. M., \& Keller, T. E. (2011). Interpersonal Tone Within School-Based Youth Coaching Relationships. Youth \& Society. http://doi.org/10.1177/0044118X11409068

Ragins, B. R., \& Kram, K. E. (2007). The roots and meaning of coaching. In B. R. Ragins, \& K. E. Kram (Eds.), The handbook of coaching at work: Theory, research and practice (pp. 317). Thousand Oaks: Sage Publications Inc.

Reagan-Porras, L. L. (2013). Dynamic Duos: A Case Review of Effective Coaching Program Evaluations. Journal of Applied Social Science, 7(2), 208-219. doi:10.1177/1936724412467019

Rekalde, I., Landeta, J., \& Albizu, E. (2015). Determining factors in the effectiveness of executive coaching as a management development tool. Management Decision, 53(8), 1677-1697.

Rhodes, J. E. (2005). A model of youth coaching. In D.L. DuBois\& M.J. Karcher (Eds.), Handbook of youth coaching (pp. 30-43). Thousand Oaks, CA: Sage.

Rhodes, J. E., \& Dubois, D. L. (2008). Coaching relationships and programs for youth. Current Directions in Psychological Science, 17(4), 254-258. http://doi.org/10.1111/j.14678721.2008.00585.x

Rigg, C., \& Trehan, K. (2008). Critical Reflection in the workplace: is it just too difficult? Journal of European Industrial Training, 374 - 384.

Sanfey, H., Hollands, C., \& Gantt, N. L. (2013). Strategies for building an effective coaching relationship. American Journal of Surgery, 206(5), 714-8. doi:10.1016/j.amjsurg.2013.08.001

Schwartz, S. E. O., Chan, C. S., Rhodes, J. E., \& Scales, P. C. (2013). Community Developmental Assets and Positive Youth Development: The Role of Natural Mentors. Research in Human Development, 10(2), 141-162. doi:10.1080/15427609.2013.786553 
Sherrod, L. (2007). Civic engagement as an expression of positive youth development. In R.K.Silbereisen, \& R. M. Lerner (Eds), Approaches to positive youth development (pp. 59-74). Thousand Oaks: Sage Publication.

Silbereisen, R. K., \& Lerner, R. M. (2007). Approaches to positive youth development. London: Sage Publications.

Sitkin, S. B., Lind, E. A., \& Siang, S. (2006). The six domains of leadership. The Frances Hesselbein Leadership, 2006(1): 27-33.

Smolter, V. (2011). Leadership development programs and generational differences (Master's thesis). The Pennsylvania State University.

Solansky, S. T. (2010). The evaluation of two key leadership development program components: Leadership skills assessment and leadership coaching. The Leadership Quarterly, 21(4), 675-681. doi:10.1016/j.leaqua.2010.06.009

Speltz, M. E. (2013). Defining critical factors in executive coaching relationships from the perspective of the executive coaching. Minneapolis: University of Minnesota.

Starr, J. (2016). The Coaching Manual. United Kingdom: Pearson Education Limited.

Theokas, C. (2005). Conceptualizing and Modeling Individual and Ecological Asset Components of Thriving in Early Adolescence. The Journal of Early Adolescence, 25(1), 113-143. doi:10.1177/0272431604272460

Ulrich, D. (2008). Coaching for results. In Business Strategy Series (pp. 104-114).

Ward, S. (2008). Atmosphere in a Positive Youth Development: A Youth Perspective. PhD Thesis, University of Northern Colorado.

Wenger, E. (1998). Communities of practice: Learning, meaning and identity. Cambridge: Cambridge University Press.

Wenger, E., McDermott, R., \& Snyder, W. M. (2002). Cultivating communities of practice. Boston: Harvard Business School Press. 